\title{
MODIFICATION OF THE SECONDARY SEX RATIO IN THE ALBINO RAT BY PROGESTERONE AND OESTROGEN THERAPY
}

\author{
E. W. HAHN* AND R. L. HAYS \\ University of Illinois, Urbana, Illinois, U.S.A.
}

(Received 29th May 1963)

\begin{abstract}
Summary. Injections of oestrogen and progesterone into pregnant rats in doses near the physiological level decreased the secondary sex ratio of the young to 80.4 males per 100 females in females ovariectomized on the 8th day of pregnancy, and increased it to 122.2 in intact females. These differences are significantly different $(P<0 \cdot 05)$ from the control sex ratio of 101.2 and highly significantly different $(P<0.005)$ from each other.
\end{abstract}

\section{INTRODUCTION}

Differences in sex ratios at birth have been reported in different species and under different environmental conditions. These reports have been reviewed by Lawrence (1941), Crew (1952), Colombo (1957) and Hahn (1961). The injection, during pregnancy, of hormones such as oestrogen (Greene, Burrill \& Ivy, 1940), cortisone (White \& DaCosta, 1960) and ACTH (Geiringer, 1961), as well as the technique of parabiosis (Hahn \& Hays, 1960) have been reported to alter the secondary sex ratio of the rat. Studies on the effectiveness of oestrogen and progestin in maintaining pregnancy in the rat under various pathogenic stimuli have raised the question of the effect of these hormones on the secondary sex ratio.

\section{MATERIALS AND METHODS}

This report is based on observations from a series of experiments having several factors in common. The females were randomly assigned to the experiments, mated with fertile males and placed on the treatment the day of mating. From Day 0 , the day of mating, through Day 7 , all females received daily subcutaneous injections of $5 \mathrm{mg}$ of progesterone in sesame oil. On Day 8, eighty females were bilaterally ovariectomized via the dorsal approach, while sixtyfour were left intact. Both groups received daily subcutaneous injections of 5 $\mathrm{mg}$ of progesterone and 0.5 $\mathrm{mg}$ oestrone on Day 8 through Day 11, and $10 \mathrm{mg}$ progesterone and $0.5 \mathrm{\mu g}$ oestrone on Day 12 through Day 20. On Day 20, the females were autopsied and the living foetuses sexed according to the method

* Present address: University of Rochester School of Medicine and Dentistry, Rochester, New York, U.S.A. 
previously described (Hahn, 1961). The adjunct treatments which the females were placed under from the day of mating were sucrose and distilled water, continuous exposure to $90^{\circ} \mathrm{F}$, and no treatment except hormone therapy. Thirty-one females served as untreated controls. Differences were statistically assessed by chi-square analysis.

\section{RESULTS}

The results of this study are found in Table 1 .

The thirty-one control animals produced a total of 340 foetuses with an average litter size of 11.0 foetuses, resulting in a sex ratio of 101.2 males per hundred females. On the other hand, eighty hormone-treated females ovariectomized on the 8th day of pregnancy produced 368 young with a sex ratio of

\section{TABLE 1}

SEX RATIOS OF FOETUSES FROM INTACT AND OVARIEGTOMIZED FEMALES REGEIVING PROGESTERONE AND OESTROGEN

\begin{tabular}{|c|c|c|c|c|c|}
\hline Treatment & No. litters & $\begin{array}{c}\text { Average } \\
\text { size of litter }\end{array}$ & No. males & $\begin{array}{c}\text { Noo. } \\
\text { females }\end{array}$ & Sex ratio \\
\hline $\begin{aligned} \text { Ovariectomized } & \text { - complete diet } \\
& \text { - sucrose diet } \\
& -90^{\circ} \mathrm{F}\end{aligned}$ & $\begin{array}{r}47 \\
27 \\
6\end{array}$ & $\begin{array}{l}4 \cdot 2 \\
5 \cdot 3 \\
4 \cdot 8\end{array}$ & $\begin{array}{l}92 \\
60 \\
12\end{array}$ & $\begin{array}{r}105 \\
82 \\
17\end{array}$ & $\begin{array}{l}87 \cdot 6 \\
73 \cdot 2 \\
70 \cdot 6\end{array}$ \\
\hline Ovariectomized-totals & 80 & $4 \cdot 6$ & 164 & 204 & $80 \cdot 4 *$ \\
\hline $\begin{array}{cl}\text { Intact } & \text {-complete diet } \\
& \text {-sucrose diet } \\
& -90^{\circ} \mathrm{F}\end{array}$ & $\begin{array}{r}32 \\
28 \\
4\end{array}$ & $\begin{array}{l}8 \cdot 9 \\
4 \cdot 5 \\
9 \cdot 8\end{array}$ & $\begin{array}{r}158 \\
68 \\
22\end{array}$ & $\begin{array}{r}127 \\
59 \\
17\end{array}$ & $\begin{array}{l}124 \cdot 4 \\
115 \cdot 3 \\
129 \cdot 4\end{array}$ \\
\hline Intact -totals & 64 & $7 \cdot 0$ & 248 & 203 & $122 \cdot 2 * \dagger$ \\
\hline Controls-totals & 31 & $11 \cdot 0$ & 171 & 169 & $101 \cdot 2$ \\
\hline
\end{tabular}

* Significant from control females at the $P<0.05$ level.

$\uparrow$ Significant from ovariectomized females at the $P<0.005$ level.

80.4, and sixty-four intact hormone-treated females produced 447 young with a sex ratio of $122 \cdot 2$, the average litter size being $4 \cdot 6$ and $7 \cdot 0$, respectively. These experimental sex ratios are significantly $(P<0.05)$ different from the sex ratio of the controls and highly significantly $(P<0.005)$ different from each other.

\section{DISCUSSION}

The determination of sex was based on the distance from the anus to the genital papilla, and this determination was verified by dissection in enough cases to show that the method was valid and that the hormones injected had not altered the genitalia of the males. Green et al. (1940) reported that oestrogen injection in the pregnant rat had no effect on the genitalia of the male offspring unless over $0.5 \mathrm{mg}$ of oestradiol propionate was given in 10 days. The majority of the work summarized by Jost (1960) seems to indicate that this is not an embryonic 
sex reversal produced by the ovarian steroids, particularly at the levels used in these experiments.

The results of this experiment and the work cited above seem to indicate that the exogenous hormones brought about a condition which led to preferential mortality or survival of one or other sex. The decrease in the average size of the litters for the intact and ovariectomized females was large enough to account for abnormal sex ratios if this were so.

In summary, therefore, data have been collected under our laboratory conditions, which indicate that the sex ratio can be significantly altered by giving exogenous ovarian steroids to ovariectomized and intact pregnant females.

\section{REFERENCES}

Colombo, B. (1957) On the sex ratio in man. Cold Spr. Harb. Symp. quant. Biol. 22, 193.

CREw, F. A. E. (1952) The factors which determine sex. Marshall's Physiology of Reproduction, 3rd edn, Chap. 22. Ed. A. S. Parkes. Longmans, Green, London.

Geiringer, E. (1961) Effect of AGTH on sex ratio of the albino rat. Proc. Soc. exp. Biol., N.Y. $106,752$.

Greene, R. R., Burrill, M. W. \& Ivy, A. C. (1940) Experimental intersexuality, the effects of estrogens on the antenatal sexual development of the rat. Amer. 7. Anat. 67, 305.

Hahn, E. W. (1961) The effect of certain internal and external environments on reproduction and sex ratio of albino rats. Ph.D. thesis, University of Illinois, Urbana.

HaHn, E. W. \& HAYs, R. L. (1960) Modification of the secondary sex ratio in rats by parabiosis (Abstract). 7. Dairy Sci. 43, 865.

Jost, A. (1960) Sex differentiation and development. Mem. Soc. Endocrin. 7, 49.

LAWRence, P. S. (1941) The sex ratio, fertility and ancestral longevity. Quart. Rev. Biol. 16, 35.

Staples, R. E., Hansel, W., Foote, R. H. \& Dunn, H. V. (1960) Motility and fertility of progesteroneand estrogen-treated bovine semen. F. Dairy Sci. 43, 787.

Whrte, M. \& DaCosta, E. (1960) Effect of cortisone on maturation of the gonads and sex ratio of rats (Abstract). Fed. Proc. 19, 150. 